\title{
Course Design for First-Year Undergraduate Human Science Programmes: A Blended Course in English for Academic Purposes
}

Laüra Hoskins

\section{CpenEdition}

Journals

Electronic version

URL: http://journals.openedition.org/asp/5558

DOI: $10.4000 /$ asp.5558

ISSN: 2108-6354

Publisher

Groupe d'étude et de recherche en anglais de spécialité

\section{Printed version}

Date of publication: 1 November 2018

Number of pages: 173-189

ISSN: $1246-8185$

\section{Electronic reference}

Laüra Hoskins, « Course Design for First-Year Undergraduate Human Science Programmes: A Blended Course in English for Academic Purposes », ASp [Online], 74 | 2018, Online since 01 November 2018, connection on 02 November 2020. URL : http://journals.openedition.org/asp/5558 ; DOI : https:// doi.org/10.4000/asp.5558

This text was automatically generated on 2 November 2020 .

Tous droits réservés 


\title{
Course Design for First-Year Undergraduate Human Science Programmes: A Blended Course in English for Academic Purposes
}

\author{
Laüra Hoskins
}

In this report about an EAP programme for undergraduate Human Sciences students at the University of Bordeaux, Laüra Hoskins offers a valuable insight into the issues at stake when designing, implementing and evaluating a blended-learning programme. The author presents the blended format as a possible solution to some of the problems mentioned in previous studies in ESP contexts, particularly in Human Sciences: institutional constraints, large numbers of students, heterogeneous levels of proficiency, low engagement, diverse needs and learning strategies. The programme combines form-focussed, topics-based online activities on a Moodle platform and face-to-face sessions. Regular speaking workshops and in-class sessions offer opportunities for language practice and group work based on the online video and text input. To take individual profiles into account, students take an initial placement test and are assigned to one of three CEF-based tracks (A1; A2-B1; B2-C1). An interesting aspect of the programme is its "learning-to-learn" approach: students are required to reflect on their learning and progress by writing a learning diary. Another strong element of the programme is the learning support provided through regular collective feedback on diaries, weekly newsletters and drop-in meetings with the course coordinator.

Although the efficiency of the course in terms of language acquisition and student engagement remains to be assessed, an evaluation of students' use of the online resources and satisfaction about the programme was carried out. The results are clearly in agreement with previous studies, as they confirm some key points to consider when designing a blended-learning programme: students' engagement in online activities depends on their level of proficiency; faceto-face sessions are highly valued both by students and teachers; and students' engagement is linked to teachers' attitudes towards the necessary collaborative work blended-learning programmes entail. (Sophie Belan) 


\section{Background}

1 The Département Langues et Cultures at the University of Bordeaux delivers English courses to over 21,000 undergraduate and postgraduate students enrolled in health or human sciences. This paper reports on a first-year English for academic purposes (EAP) course that was designed in 2016 and implemented for the first time in January 2017. The course was originally intended for the 650 first-year students reading psychology and sociology, but has since been partially extended to include 400 first-year sport science students. The course, English for Psychology and Sociology, runs through the ten weeks of the second semester of the academic year and combines in-class face-toface sessions with online modules in a blended format. It was created in response to a number of institutional and pedagogical difficulties that will now be described.

\section{Learner profiles}

2 Undergraduate programmes at French universities have only recently been permitted by law to select university applicants according to criteria determined by higher education professionals. Human science degree programmes have traditionally attracted large numbers of school leavers with varying levels of English proficiency. On starting the first-year English course, students enrolled in these programmes at Bordeaux take a placement test ${ }^{1}$ to have an indication of their level in English. Students are also required to complete a pre-course questionnaire which, among some of the questions, invites them to reflect on their language learning experiences to date and indicate the strategies they have put in place to improve their English.

3 The results of students tested in January 2018 at the start of their English course reveal generally low levels of proficiency with over half the students in first-year psychology or sociology (372) obtaining an A2 score or less. Only around $36 \%$ of students obtained scores indicating B1 level proficiency or above. This contrasts with more selective tracks, such as dentistry, where almost $70 \%$ of first-year students obtained B1 scores in 2016.

4 The language learning habits of incoming human science students also vary widely. Unsurprisingly, results from the 2018 pre-course questionnaire show that these habits are correlated with levels of proficiency (Appendix 1). Incoming students with a B2 or C1 level were much more likely to be engaging in informal learning activities such as watching videos, reading or online interactions in English than A1 or A2 students were. The stronger students also indicated that they had engaged more in formal learning activities such as oral participation in class or personal work after school than the weaker students did. Just under $65 \%$ of the latter (about $40 \%$ of the total cohort) said they carried out personal work after school never or not very regularly, highlighting the need to engage first-year students in language learning and help them develop good learner habits.

\section{Teaching context}

5 The large student numbers together with the unevenly balanced but generally low levels of proficiency in English and poor learner engagement meant that first-year 
human sciences was until recently a sector largely avoided by permanent staff, in preference for more motivating areas such as medicine, dentistry or biology. This had created a strong reliance on temporary, externally recruited and more inexperienced teaching staff, which in turn compromised continuity from one year to the next. This reliance also made it difficult to harmonise practices across the 27 groups. The solution that had been found was to set a B1 level textbook of general English as the course syllabus, which was not very motivating for the teachers or the students. The previous format provided for a scant $16 \mathrm{~h}$ of face-to-face English tuition, spread over the two semesters ( $4 \times 2 \mathrm{hr}$ classes per semester) and no online support: too little and too diluted to promote good learning habits and lead to any progress.

Groups were streamed according to ability, in an attempt to cater for the variety of levels, but this only seemed to exacerbate some of the difficulties. As every teacher followed the same textbook, weaker groups had difficulty engaging in the materials and remained passive, while stronger groups were under-stimulated and bored. Teachers felt frustration at the lack of student engagement and struggled to generate interaction between students, some of whom even displayed disruptive behaviour in class. Student satisfaction levels were felt by the teachers to be low. The programme was also costly in terms of teaching hours (480h), with arguably little impact on the students' English skills and appetite for learning English. When combined with the typically high dropout in $1^{\text {st }}$ year, the programme made ineffective use of the human resources and technological resources available.

7 In 2015-16 therefore, when degree programmes were being updated nationally, and after consultation with the human science faculties, the Département Langues et Cultures proposed a complete overhaul of English courses for undergraduate programmes in psychology and sociology. Teaching hours were redistributed towards $2^{\text {nd }}$ and $3^{\text {rd }}$ year English, where student numbers were lower, and a blended learning format was designed for $1^{\text {st }}$ year English, ${ }^{2}$ a programme which is now implemented by six permanent members of staff for a total cost of 229 teaching hours.

\section{A blended learning format}

8 The main intended learning outcome of the course is better engagement among learners in the language learning process. Drawing from Stephen Bowen's (2005) definition of "engaged learning", the first-year English programme aims to help students learn to learn English, according to their needs, engage with their discipline in English and interact with their peers and teachers in English in an academic context. In so doing, the programme offers more generally a safe, low stakes space for students to acquire the habits of engaged learners. The programme provides rich input through reading and listening tasks, accompanied by pronunciation, grammar and vocabulary activities. It also provides opportunities for productive practice in the form of speaking workshops and metacognitive reflection via a learning diary.

9 At the start of the course, students take a placement test to assign them to one of three tracks and place them in a group for face-to-face sessions: level 1 (A1 learners), level 2 (A2-B1 learners), level 3 (B2-C1 learners). The organisation and objectives of the course are explained in an introductory lecture for all students. From then on, the blend differs according to the track, as shown in Table 1. Online and face-to-face activities are also differentiated. Students are allocated evenly across the groups in each track 
according to their level, so that each group is equally heterogeneous. This organisation, whereby all the level 2 groups and all the level 3 groups are equivalent in terms of level, aims to leverage the language diversity of the cohort to its advantage and capitalise on the formative potential of peer-to-peer instruction for learners of all levels.

Table 1: Course organisation

\begin{tabular}{|c|c|c|c|c|c|}
\hline CEF & Track & Face-to-face & Online & $\mathrm{N}^{\circ}$ of groups (2018) & $\mathrm{N}^{\circ}$ of students (2018) \\
\hline A1 & Level 1 & $\begin{array}{l}1 \times 1 \mathrm{~h} \text { lecture } \\
10 \times 2 \mathrm{~h} \text { classes }\end{array}$ & $5 \mathrm{~h}+$ & 1 & 27 \\
\hline A2 & \multirow{2}{*}{ Level 2} & \multirow{4}{*}{$\begin{array}{l}1 \times 1 \mathrm{~h} \text { lecture } \\
5 \times 1 \mathrm{~h} \text { workshops }\end{array}$} & \multirow{4}{*}{$5 \times 4 h$ modules } & \multirow{2}{*}{24} & \multirow{2}{*}{509} \\
\hline B1 & & & & & \\
\hline B2 & \multirow{2}{*}{ Level 3} & & & \multirow{2}{*}{6} & \multirow{2}{*}{64} \\
\hline $\mathrm{C} 1$ & & & & & \\
\hline C2 & exempt & & & & 3 \\
\hline
\end{tabular}

10 A Moodle-supported learning platform ( Figure 1) houses the online activities (Figure 2) of the modules that make up the course and provides a space to keep students informed about the organisation of the course via a news forum, timetable postings and feedback videos. The English modules take their themes from a core disciplinary course that all human science students study at the University of Bordeaux: SHS Pour Tous (Human Sciences for Everyone). The themes provide a broad introduction to psychology, sociology, sport as well as anthropology and educational sciences topics: Education, Health, Ages, Discrimination, Risk. An overview of the modules of the English course is shown in Appendix 2. Each module spans two weeks. 
Figure 1: Screen capture of the Moodle learning space

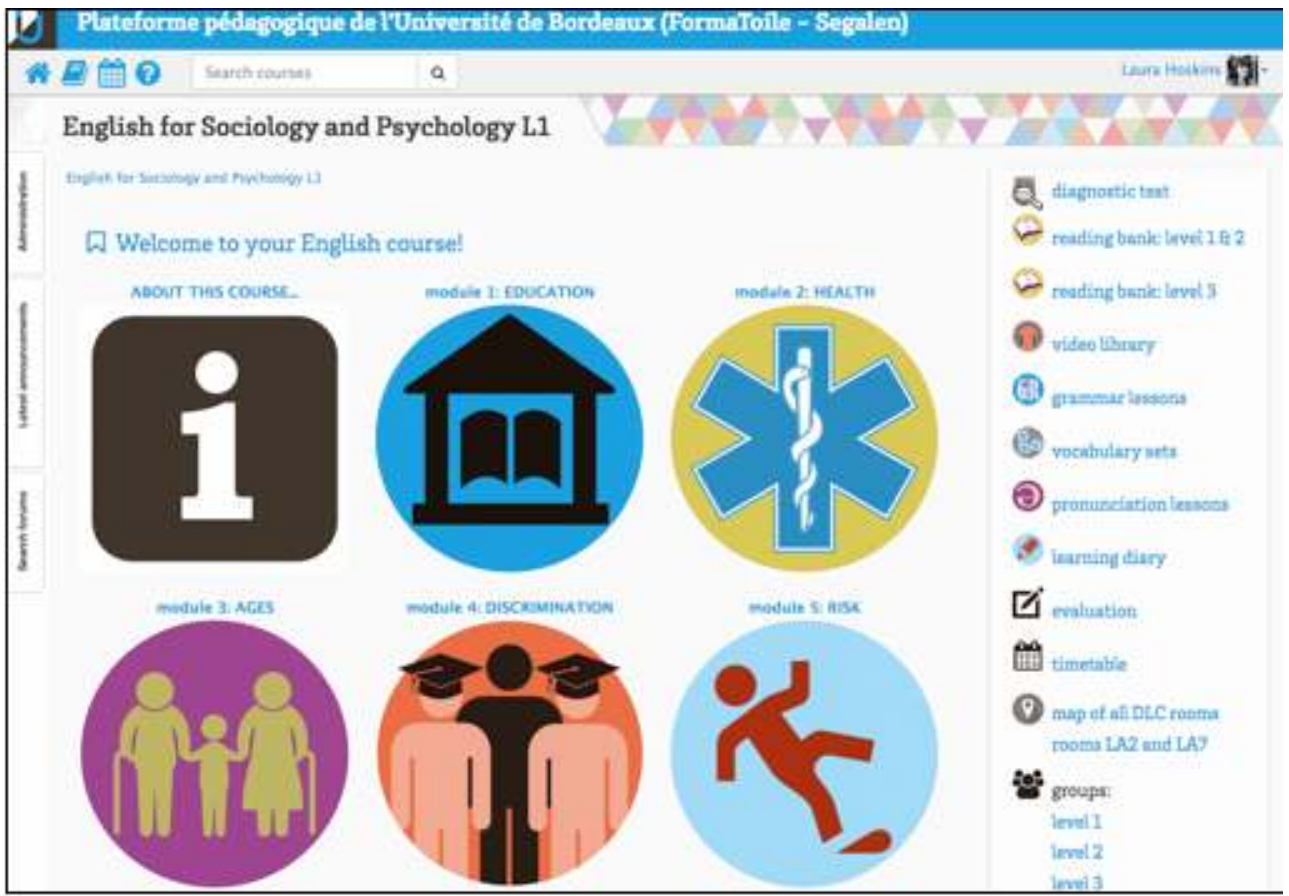

Figure 2: Screen capture of the activities in an online module

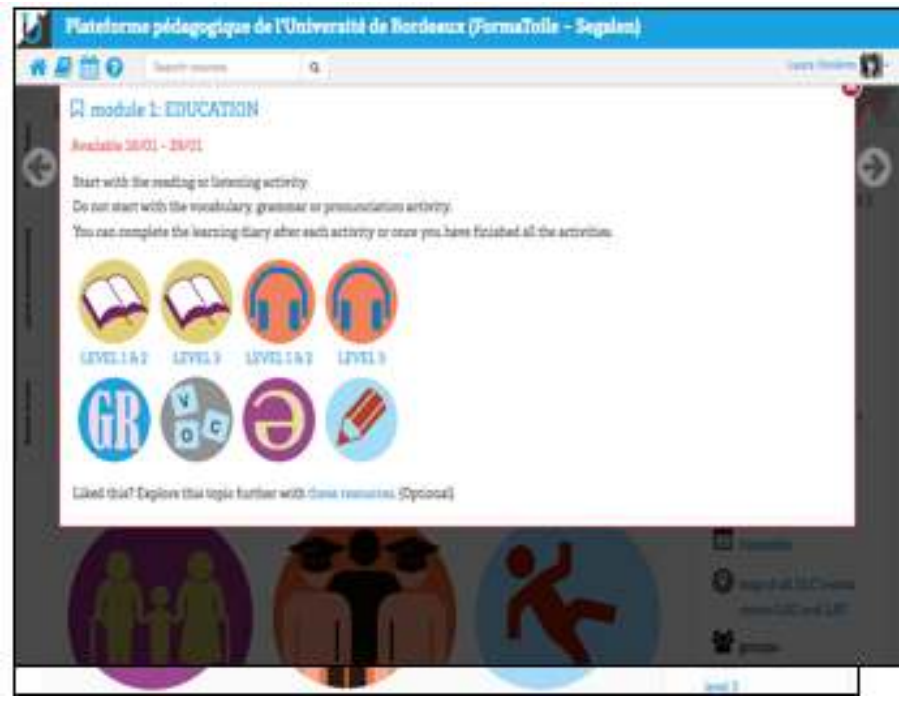

11 Online, level 2 and level 3 students explore these themes through a series of activities based on texts and videos taken from the mainstream media. These activities are differentiated, with abridged versions of the text and video for the level 2 track, but students are free to work on the easier (level 2) or harder (level 3) activities. Learners are encouraged to develop their language skills via pronunciation, vocabulary and grammar quizzes. Video lessons created for the course in the form of paperslide videos and Powtoon videos provide the basis for the pronunciation and grammar quizzes, while the vocabulary activities focussing on the core academic vocabulary in the resources are supported by Quizlet. Students are finally invited to keep a record of and reflect on their learning through a learning diary (Moodle journal), that also serves as an assessment tool (30\% of the final grade). Level 2 students are required to write at 
least 200 words for each module and are guided by a set of prompts about the online resources and face-to-face activities (e.g. sum up the resources in this module [who? what? where? when?] and give your reaction). Level 3 students, on the other hand are given more freedom to write a 500-word blog-style post with a given title (e.g. Thoughts on the Use of Technology in Education). Students in the level 1 track complete their learning diary with the help of their teacher, whom they see every week. In class, level 2 and level 3 students complete speaking tasks that feed into and build on the resources seen online. Students attend speaking workshops in groups of no more than 20 students every two weeks. The workshops are highly interactive and low-tech, as students complete tasks by mingling, forming pairs or groups, ranking, defining, describing, etc. while the teacher facilitates, monitors, and provides feedback. Activities designed for the level 3 groups are more challenging, with mini-debates and discussions. Students in the leve 1 track on the other hand, are guided through the course materials in smaller chunks in class and complete basic communicative activities.

Further learning support is provided through various channels:

1. Weekly newsletters via the news forum where frequently asked questions asked by individual students are answered by the course coordinator.

2. Fortnightly paperslide videos, made by course teachers, where collective feedback on the learning diaries is given. Frequently committed mistakes are for example reviewed and the teacher offers tips for improving writing. Students are able to modify their writing throughout the course based on the advice given in these videos.

3. Weekly face-to-face drop-in sessions at the Language Centre with the course coordinator.

\section{Assessment}

14 Students are assessed by continuous assessment and final exam. For each part they obtain a mark out of 20 . The continuous assessment mark represents $50 \%$ of the final mark for the course and is broken down into two parts: $20 \%$ is for attendance and activity completion (i.e. by attending all the classes and completing all the activities, a student can gain $8 / 20$ ) and $30 \%$ is for the quality of the learning diary (maximum 12/20). The assessment criteria for the learning diary shown in Assessment. The final exam counts for the remaining $50 \%$ of the final mark and is a 1-hour 60 -question multiple choice test that includes comprehension questions on excerpts from the resources seen during the course as well as pronunciation, vocabulary and grammar questions.

Table 2: Rubric for marking the Learning Diary (/12)

\begin{tabular}{|c|c|c|c|c|c|c|}
\hline \multirow[t]{8}{*}{ content } & \multirow[b]{3}{*}{$\mathbf{F}$} & & \multirow{2}{*}{ C } & \multirow{2}{*}{ B } & \multirow[b]{2}{*}{ vomu reod } & \multirow{2}{*}{$\begin{array}{l}A^{*} \\
\text { excellent }\end{array}$} \\
\hline & & & & & & \\
\hline & & & satisfactory & all entries & all entries & all entries \\
\hline & & & all entries & completed, & & with always \\
\hline & entries & entries & completed & with often & & \\
\hline & incomplete and & incomplete or & with & well- & always & develoned \\
\hline & underdeveloped & underdeveloped & satisfactorily & developed & Well- & intelligent \\
\hline & answers & answers & $\begin{array}{l}\text { developed } \\
\text { answers }\end{array}$ & $\begin{array}{l}\text { and } \\
\text { intelligent }\end{array}$ & $\begin{array}{l}\text { developed } \\
\text { and }\end{array}$ & and \\
\hline $\mathrm{ASp}, 74 \mid 2$ & & & & answers & $\begin{array}{l}\text { intelligent } \\
\text { answers }\end{array}$ & $\begin{array}{l}\text { original } \\
\text { answers }\end{array}$ \\
\hline
\end{tabular}




\begin{tabular}{|l|l|l|l|l|l|l|}
\cline { 1 - 4 } language & & & & & & \\
\hline pre-A1 & 1 & 2 & 3 & 4 & 5 & 6 \\
\hline A1 & 2 & 3 & 4 & 5 & 6 & 7 \\
\hline A2 & 3 & 4 & 5 & 6 & 7 & 8 \\
\hline B1 & 4 & 5 & 6 & 7 & 8 & 9 \\
\hline B2 & 5 & 6 & 7 & 8 & 9 & 10 \\
\hline C1 & 6 & 7 & 8 & 9 & 10 & 11 \\
\hline C2 & 7 & 8 & 9 & 10 & 11 & 12 \\
\hline
\end{tabular}

\section{Outcomes}

\section{Student Outcomes}

Data collected from several sources will be analysed here to evaluate the outcomes of the course for the 2017-2018 cohort of students. Data on activity completion was extracted automatically from the Moodle page and a post-course questionnaire was administered using the Moodle feedback module. The post-course questionnaire comprised 46 questions and collected 323 responses, over half of the enrolled cohort. Students were asked about their use of the learning space and levels of satisfaction, with open questions for comments and recommendations.

Regarding the online component of the course, activity completion was generally high, above all among the stronger students, with just under $75 \%$ of students in the level 3 track (B2/C1) completing 21-25 activities, 25 being the maximum number (Outcomes). Just under half the students in the level 2 track (A2/B1) completed 21-25 activities. However, it should be noted that these data indicate only whether the student submitted the activity, not how much time they dedicated to it or what score they obtained. Students also knew that just completing the activities would gain them $20 \%$ of their final mark.

Responses to the questionnaire also revealed that a majority of students claimed to have used the materials, advice and opportunities made available to them (Tabl). About $90 \%$ of respondents said they had participated orally in the speaking workshops they attended, though due to a student sit-in in March-April 2018 only three out of the planned five speaking workshops were able to take place. Just over $60 \%$ completed their learning diary as they moved through the modules and acted on the video feedback delivered by teachers. In terms of satisfaction, the majority of respondents appear satisfied overall (Table). Attitudes were, however, more positive for the face-face-face component, despite the number of sessions being cut due to the student sit-in. Indeed, when asked to identify the main asset of the course in the open questions, students most frequently cited the workshops. 
Table 3: Online activity completion

\begin{tabular}{|l|l|l|l|l|}
\hline & \multicolumn{2}{|l|}{ Level 2 students } & \multicolumn{2}{l|}{ Level 3 students } \\
\hline $\mathrm{N}^{\circ}$ of activities completed & $\mathrm{N}^{\circ}$ of students & $\%$ & $\mathrm{~N}^{\circ}$ of students & $\%$ \\
\hline 0 to 5 & 47 & 9.63 & 5 & 7.94 \\
\hline 6 to 10 & 38 & 7.79 & 4 & 6.35 \\
\hline 11 to 15 & 44 & 9.02 & 4 & 6.35 \\
\hline 16 to 20 & 51 & 10.45 & 3 & 4.76 \\
\hline 21 to 25 & 308 & 63.11 & 47 & 74.60 \\
\hline
\end{tabular}

Table 4: Usage of online support

\begin{tabular}{|l|l|l|}
\hline \multicolumn{2}{|l|}{} & $\begin{array}{l}\text { N of respondents } \\
\text { answering... }\end{array}$ \\
\cline { 2 - 3 } & Yes & No \\
\hline Did you read the English updates regularly? & 228 & 94 \\
\hline $\begin{array}{l}\text { Did you download the Quizlet application to learn and revise } \\
\text { vocabulary? }\end{array}$ & 192 & 137 \\
\hline $\begin{array}{l}\text { Did you record yourself or speak out loud when doing the } \\
\text { pronunciation activities? }\end{array}$ & 197 & 126 \\
\hline $\begin{array}{l}\text { Did you complete your learning diary as you moved through the } \\
\text { modules? }\end{array}$ & 265 & 59 \\
\hline Did you watch the learning diary feedback videos? & 214 & 103 \\
\hline Did you then modify your learning diary accordingly? & 203 & 29 \\
\hline Did you participate orally in the speaking workshops you went to? & 289 & 113 \\
\hline
\end{tabular}

Table 5: Student satisfaction

\begin{tabular}{|l|l|l|}
\hline & \multicolumn{2}{|l|}{$\mathrm{N}^{\circ}$ of respondents (all tracks combined) } \\
\cline { 2 - 3 } & Online component & Face-to-face component \\
\hline Not at all satisfied & 38 & 6 \\
\hline Mostly not satisfied & 70 & 37 \\
\hline
\end{tabular}




\begin{tabular}{|l|l|l|}
\hline Mostly satisfied & 158 & 133 \\
\hline Completely satisfied & 68 & 137 \\
\hline
\end{tabular}

Finally, regarding achievement, marks were distributed in a bell curve for both continuous assessment and the final exam (Figure 6). Furthermore, over $50 \%$ of students (190) identified as having an A2 level in English at the start of the course were able to validate the English course (Table 6), (with the B2 and C1 students obtaining predictably the highest scores. Only the three students identified as having a C2 level obtained lower than expected grades in the final exam. These students were exempt from the continuous assessment part of the course. For future years these exemptions should not be allowed as it appears that even if students have a C2 level in general English, they could benefit from following an English for Academic Purposes course.

Table 6: Overall achievement: Marks according to initial level

\begin{tabular}{|l|l|l|l|l|l|l|l|}
\hline $\begin{array}{l}\text { overall mark } \\
\text { /20 }\end{array}$ & $\begin{array}{l}\text { A1 } \\
\text { students }\end{array}$ & $\begin{array}{l}\text { A2 } \\
\text { students }\end{array}$ & $\begin{array}{l}\text { B1 } \\
\text { students }\end{array}$ & $\begin{array}{l}\text { B2 } \\
\text { students }\end{array}$ & $\begin{array}{l}\text { C1 } \\
\text { students }\end{array}$ & $\begin{array}{l}\text { C2 } \\
\text { students }\end{array}$ & $\begin{array}{l}\text { students } \\
\text { unknown level }\end{array}$ \\
\hline$>=0,<5$ & 2 & 24 & 9 & 1 & 0 & 0 & 2 \\
\hline$>=5,<10$ & 12 & 124 & 23 & 4 & 0 & 0 & 12 \\
\hline$>=10,<15$ & 9 & 190 & 100 & 14 & 2 & 1 & 9 \\
\hline$>=15,<=20$ & 1 & 8 & 32 & 32 & 11 & 2 & 1 \\
\hline
\end{tabular}

Though encouraging, all these indicators give little insight into whether students actually progressed in English thanks to the course or whether their engagement in the learning process evolved during the course. With a view of measuring the students' perception of their progress, the pre-course and post-course questionnaire included identical items relating to language skills. The B2 descriptors of the Common European Framework (Council of Europe 2017) were given and students asked to rate how easily they were able to complete each task. The responses to these items are shown in Appendix 3 and Appendix 4. There is no obvious difference between the students' responses at the start and end of the course. Either students did not progress, or this method for assessing progress is flawed. The time lapse between the two questionnaires may have been insufficient or students may not be the best placed to assess their language abilities. Future studies of this course might therefore include a pre-course and post-course test for a more objective measure.

20 Similarly, as far as attitudes to learning English go, there seems to be no significant difference between the results of the pre-course questionnaire and the results of the post-course questionnaire (Appendix 5 and Appendix 6). Again, perhaps the 10-week duration of the English course is not enough to see a significant difference in engagement or attitudes, but it would perhaps be more interesting to follow students as they move up the degree programme to observe any differences in attitude or engagement. 


\section{Limitations}

21 After discussion and reflection, the teaching team identified a number of limitations with the course that should be taken into consideration for future versions of the programme. Firstly, though it provides rich input, the programme is not a task-based course but a topics-based one. There may thus be a sense for students that they are completing the activities for the benefit of the teacher and obtaining a grade rather in view of completing a final task. Students could benefit from a task-based approach to guide and give purpose to their language learning. Secondly, it could be argued with its set pathways and highly scaffolded activities for the different tracks, the course does not develop learner autonomy sufficiently, as students are simply completing a series of steps defined by the teacher and not learning to take on the work that would be typically by carried out by an instructor. While the level 3 track does offer students more freedom to select and report on the resources they wish to study, the level 1 \& 2 tracks do not. It would be worth exploring ways of achieving greater learner autonomy in future versions, by offering for example a selection of materials curated by level for learners to choose from in addition to the set resources. A common core is though necessary while part of the assessment it based on a final exam.

\section{Teacher Outcomes}

Although the online component, of course, was designed by one teacher-coordinator, it was user-tested and implemented by a team of permanent teachers, and this is perhaps the most significant positive outcome of the course. During the first year of the course, face-to-face sessions were designed collaboratively and became the object of regular debriefs and exchanges of practice to improve the quality of interactions from one week to the next. The teachers said they enjoyed teaching the course and noted that students were engaged and happy to participate during the face-to-face sessions.

Teachers were contacted by email in May 2017 to give their feedback on the course and in particular their views on how it fostered engagement in staff and students. Their insights are summed up in Appendix 7. Like the students, the teachers also noted the value of the speaking workshops. This highlights the need to give special attention to face-to-face input materials and output activities in the design of blended courses as they seem to play a central role in engaging students.

\section{Conclusion}

This paper has reported on the design, implementation and evaluation of a blended learning course for EAP learners in first-year psychology and sociology. Course completion and student satisfaction were relatively high, but it remains to be seen whether the course can have an impact on learner progress and engagement. However, teacher feedback shows the benefits that can be derived from ESP teachers working collaboratively, as part of a teaching team, in planning, implementing, and evaluating blended learning systems. Indeed, in his 2015 paper review, John Hattie places collective teacher efficacy second on the list of influences on student achievement in higher education and makes the case for a collaborative approach: "A key question is 
how to build the capacity of teachers and university administrators to collectively build and evaluate successful teaching programs and learning experiences" (Hattie 2015: 90).

I would like to thank my colleagues at the Département Langues et Cultures for their input and feedback on the course design and their enthusiasm and dedication to implementing and evaluating the course year after year: Lindsay Bergstrom, Valérie Braud, Sara Garfield, Salimatu Jalloh, Brendan Mortell and Pascale Swendsen.

\section{BIBLIOGRAPHY}

BOWEN, Stephen. 2005. “Engaged learning: Are we all on the same page?”. Peer Review 7/2, 4-7.

Council of Europe. 2017. "Common European Framework of Reference for Languages: Learning, Teaching, Assessment", retrieved from <https://rm.coe.int/1680459f97> on 17/09/2018.

HATTIE, John. 2015. "The applicability of visible learning to higher education". Scholarship of Teaching and Learning in Psychology 1/1, 79-91.

\section{APPENDIXES}

Appendix 1: Language learning habits of incoming students

\begin{tabular}{|c|c|c|c|c|c|c|c|}
\hline & & $\begin{array}{l}\text { watching } \\
\text { videos in } \\
\text { English }\end{array}$ & $\begin{array}{l}\text { reading } \\
\text { in } \\
\text { English }\end{array}$ & $\begin{array}{l}\text { oral } \\
\text { participation } \\
\text { at school }\end{array}$ & $\begin{array}{l}\text { online } \\
\text { interactions } \\
\text { in English }\end{array}$ & $\begin{array}{l}\text { personal } \\
\text { work } \\
\text { after } \\
\text { school }\end{array}$ & $\begin{array}{l}\text { face-to-face } \\
\text { interactions }\end{array}$ \\
\hline \multirow{4}{*}{$\begin{array}{l}\mathrm{B} 2 / \mathrm{C} 1 \\
\text { respondents }\end{array}$} & never & 0 & 0 & 5 & 6 & 6 & 5 \\
\hline & $\begin{array}{l}\text { not very } \\
\text { regularly }\end{array}$ & 3 & 12 & 10 & 14 & 19 & 23 \\
\hline & regularly & 7 & 20 & 19 & 19 & 11 & 17 \\
\hline & $\begin{array}{l}\text { very } \\
\text { regularly }\end{array}$ & 53 & 31 & 29 & 23 & 26 & 18 \\
\hline \multirow{3}{*}{$\begin{array}{l}\text { B1 } \\
\text { respondents }\end{array}$} & never & 9 & 15 & 9 & 14 & 43 & 41 \\
\hline & $\begin{array}{l}\text { not very } \\
\text { regularly }\end{array}$ & 21 & 80 & 68 & 65 & 74 & 85 \\
\hline & regularly & 56 & 50 & 57 & 60 & 29 & 31 \\
\hline
\end{tabular}




\begin{tabular}{|l|l|l|l|l|l|l|l|}
\cline { 2 - 9 } & $\begin{array}{l}\text { very } \\
\text { regularly }\end{array}$ & 78 & 17 & 30 & 21 & 17 & 6 \\
\hline never & 43 & 141 & 32 & 45 & 182 & 142 \\
\cline { 2 - 9 } \\
$\begin{array}{l}\text { A1/A2 } \\
\text { respondents } \\
\text { not very } \\
\text { regularly }\end{array}$ & 120 & 166 & 177 & 191 & 126 & 179 \\
\cline { 2 - 9 } & regularly & 128 & 49 & 110 & 111 & 41 & 37 \\
\cline { 2 - 9 } & $\begin{array}{l}\text { very } \\
\text { regularly }\end{array}$ & 78 & 12 & 48 & 21 & 18 & 8 \\
\hline
\end{tabular}

Appendix 2: Overview of input materials

\begin{tabular}{|c|c|c|c|c|}
\hline Core Theme & English Topic & Text resource & Video resource & $\begin{array}{l}\text { Pronunciation } \\
(\mathrm{PH}), \quad \text { Grammar } \\
(\mathrm{GR})\end{array}$ \\
\hline Education & $\begin{array}{l}\text { Technology in } \\
\text { Education }\end{array}$ & $\begin{array}{l}\text { Goodbye, paper: What } \\
\text { we miss when we read } \\
\text { on screen, New Scientist } \\
\text { Magazine }\end{array}$ & $\begin{array}{lr}\text { What a } & \text { 'flipped' } \\
\text { classroom } & \text { looks } \\
\text { like, } & \text { PBS } \\
\text { NewsHour } & \end{array}$ & $\begin{array}{l}\text { PH: Introduction } \\
\text { to key issues in } \\
\text { pronunciation } \\
\text { GR: Grammar } \\
\text { words }\end{array}$ \\
\hline Health & $\begin{array}{l}\text { Alcoholism and } \\
\text { Society }\end{array}$ & $\begin{array}{l}\text { How do we tackle } \\
\text { alcoholism? First, stop } \\
\text { denying that it's part } \\
\text { of the culture of } \\
\text { poverty, The } \\
\text { Independent }\end{array}$ & $\begin{array}{l}\text { The great British } \\
\text { booze problem: } \\
\text { how a few glasses a } \\
\text { day has led to an } \\
\text { epidemic for the } \\
\text { NHS, The Guardian }\end{array}$ & $\begin{array}{l}\text { PH: Sounds: } \\
\text { schwa } \\
\text { GR: Nouns - } \\
\text { countable vs } \\
\text { uncountable, } \\
\text { articles }\end{array}$ \\
\hline Ages & $\begin{array}{l}\text { Intergenerational } \\
\text { Cooperation }\end{array}$ & $\begin{array}{l}\text { Intergenerational } \\
\text { houses bring seniors, } \\
\text { 20-somethings } \\
\text { together, Chicago } \\
\text { Tribune }\end{array}$ & $\begin{array}{l}\text { Seniors home } \\
\text { brings young and } \\
\text { old together, CBC } \\
\text { News }\end{array}$ & $\begin{array}{l}\text { PH: Sounds - } \\
\text { vowels } \\
\text { GR: Verb tenses }\end{array}$ \\
\hline Discrimination & $\begin{array}{l}\text { Racial Bias and } \\
\text { Racial Targeting }\end{array}$ & $\begin{array}{l}\text { Racial Bias, Even When } \\
\text { We Have Good } \\
\text { Intentions, The New } \\
\text { York Times }\end{array}$ & $\begin{array}{l}\text { A Conversation } \\
\text { With Police on } \\
\text { Race, } \\
\text { The New York } \\
\text { Times }\end{array}$ & $\begin{array}{l}\text { PH: Words - } \\
\text { stress } \\
\text { GR: Adjectives }\end{array}$ \\
\hline Risk & $\begin{array}{l}\text { Risk-taking } \\
\text { Youth }\end{array}$ & $\begin{array}{l}\text { Is teenage risk-taking } \\
\text { vital for our species? } \\
\text { The Guardian }\end{array}$ & \begin{tabular}{|lr} 
Skating on the \\
Edge: Why are \\
Young Men such \\
Reckless risk- \\
takers? \\
Catalyst
\end{tabular} & $\begin{array}{l}\text { PH: Connected } \\
\text { speech - rising } \\
\text { and falling } \\
\text { intonation } \\
\text { GR: The passive }\end{array}$ \\
\hline
\end{tabular}


Appendix 3: Students' perceived proficiency BEFORE the course

\begin{tabular}{|c|c|c|c|c|c|}
\hline & $\begin{array}{l}\text { with great } \\
\text { difficulty }\end{array}$ & $\begin{array}{l}\text { mostly with } \\
\text { difficulty }\end{array}$ & $\begin{array}{l}\text { mostly } \\
\text { easily }\end{array}$ & $\begin{array}{l}\text { very } \\
\text { easily }\end{array}$ & $\begin{array}{l}\text { I don't } \\
\text { know }\end{array}$ \\
\hline $\begin{array}{l}\text { I can understand extended speech and } \\
\text { lectures and follow even complex lines of } \\
\text { argument provided the topic is reasonably } \\
\text { familiar. }\end{array}$ & 29 & 119 & 155 & 35 & 4 \\
\hline $\begin{array}{l}\text { I can understand most TV news and current } \\
\text { affairs programmes. }\end{array}$ & 34 & 117 & 151 & 29 & 11 \\
\hline $\begin{array}{l}\text { I can understand the majority of films in } \\
\text { standard dialect. }\end{array}$ & 32 & 122 & 152 & 31 & 5 \\
\hline $\begin{array}{l}\text { I can read articles and reports concerned } \\
\text { with contemporary problems in which the } \\
\text { writers adopt particular attitudes or } \\
\text { viewpoints. }\end{array}$ & 34 & 109 & 150 & 35 & 14 \\
\hline $\begin{array}{l}\text { I can interact with a degree of fluency and } \\
\text { spontaneity that makes regular interaction } \\
\text { with native speakers quite possible. }\end{array}$ & 46 & 147 & 114 & 24 & 11 \\
\hline $\begin{array}{l}\text { I can take an active part in discussion in } \\
\text { familiar contexts, accounting for and } \\
\text { sustaining my views. }\end{array}$ & 40 & 121 & 149 & 26 & 6 \\
\hline $\begin{array}{l}\text { I can present clear, detailed descriptions on } \\
\text { a wide range of subjects related to my field } \\
\text { of interest. }\end{array}$ & 45 & 133 & 129 & 27 & 8 \\
\hline $\begin{array}{l}\text { I can explain a viewpoint on a topical issue } \\
\text { giving the advantages and disadvantages of } \\
\text { various options. }\end{array}$ & 48 & 164 & 99 & 18 & 13 \\
\hline $\begin{array}{l}\text { I can write clear, detailed text on a wide } \\
\text { range of subjects related to my interests. }\end{array}$ & 44 & 110 & 148 & 35 & 5 \\
\hline $\begin{array}{l}\text { I can write an essay or report, passing on } \\
\text { information or giving reasons in support of } \\
\text { or against a particular point of view. }\end{array}$ & 28 & 108 & 158 & 38 & 10 \\
\hline
\end{tabular}

\section{NOTES}

1. Oxford Quick Placement Test based on CEFR levels.

2. The programme re-design was supported institutionally in the form of a 96-hour bonus for the course designer, the author of this paper. 
INDEX

Mots-clés: anglais universitaire, apprentissage mixte, formation en sciences humaines, compte rendu d'expérience

Keywords: blended course, human science programme, EAP, teaching practices

\section{AUTHOR}

\section{LAÜRA HOSKINS}

Laüra Hoskins is an English for Specific Purposes teacher at the University of Bordeaux where she coordinates and teaches courses for undergraduate students in health and human sciences. She is also involved in teacher development for English medium instruction (EMI) and the international classroom through her work for Défi international <https://idex.u-bordeaux.fr/fr/ n/Structures-d-aide-aux-projets/Defi-international/r3088.html>. Her current interests are in blended learning and course design. laura.hoskins@u-bordeaux.fr 